\title{
Learning in London: The Architectural Association and Early Twentieth-Century New Zealand Architects
}

The 2005 New Zealand Institute of Architects' (NZIA) centenary conference highlighted the experience of expatriate architects; in a similar vein the ninth issue of Interstices examined various aspects of expatriate design and theory (Gatley \& Douglas 2008). Essays in the latter discussed the provenance of Amyas Connell's High and Over House in England (1929-31) and Wellington's Dixon Street Flats (1941-44). This article steps further into the past, to the early twentieth century when what is known colloquially as the "big OE" was "born" and first-generation Pākehā New Zealanders were drawn "Home" to study architecture. ${ }^{1}$

The story of the overseas experience of New Zealand writers, artists, and performers is widely known and well documented (Bones 2018; Dunn 1984-85; Edmond 2017; Swarbrick 2014). Similarly, the success of expatriate Kiwi scientists, actors, and singers, both historically and in the modern day, is commonly heralded in the media, even when some of the folk New Zealanders like to claim as their own left these shores as children. While New Zealand can scarcely claim an architect of the fame or stature of Ernest Rutherford or Lorde, the centenary of the University of Auckland's School of Architecture and Planning offered an opportunity to shine the spotlight on a group of New Zealanders who used study at London's Architectural Association School of Architecture (AA) to progress their education and enhance their professional development. That they did so at the same time as the foundation of the School of Architecture and Planning is further proof of the global movement to formalise architectural education in the early twentieth century (for context, see McEwan 1999).

\section{Modern Learning at the AA}

The AA was established in London in 1847. Against the backdrop of John Summerson's 1947 centenary history of the association, Mark Crinson and Jules Lubbock (1994) have identified the role played by the AA in the modernisation of the architectural profession in Britain. In the latter half of the nineteenth century, the AA, along with the Royal Academy, University College, and King's College in London, modelled a new educational path for architects that was subsequently developed by full-time academic programmes such as that offered at Liverpool University. According to Crinson and Lubbock, the AA, with its "anti-pupillage" 
emphasis on design, "came to play a significant role in fostering most of the theories that came to reform architectural education" (1994: 56). New Zealanders who attended the AA in the late nineteenth and early twentieth centuries were therefore not only circumventing contemporary colonial limitations in the educational sphere but were also at the forefront of modern architectural education.

References to the AA appear in New Zealand newspapers from the 1880s, with possibly the earliest mention of membership by a New Zealand architect involving Frederick de Jersey Clere ("Industrial Association" 1880; "Labour Disputes” 1891; Untitled 1886). Clere (1856-1952), who stated he became a member of the AA during his time working in London in the mid-1870s (Clere 1917; "F. de J. Clere" 1917; Maclean 1993), is something of an outlier in this respect, given that the connection between the AA and New Zealand architecture is largely a twentieth-century one.

\begin{abstract}
A notification appears in our advertising columns to the effect that Messrs. Atkins and Clore, the Wangandi architecta, are opening an office in Wellington. Messr8. Atkins and Clere hold the posts of diocesan arcbitosts and architeots to the Wanganui Education Board. Mr. Clere (who will ropresent the firm in this city) brings another testimony to his ability in the fact of his being an associste of the Royal Institute of British Arohiteots. He is also a member of the rociety of Arts, and war, whon resident in London, a member of the Architeotaral Association.
\end{abstract}

Fig. 1 Newspaper article mentioning Frederick de Jersey Clere's membership of the AA. [Evening Post, February 26, 1886, 2. PapersPast, National Library of New Zealand, Wellington]
Apart from Clere, 15 of the architects included in the "New Zealand Architecture Family Tree" (Barrie 2008) studied at the AA, according to the association's records. Of these, Heathcote Helmore and Guy Cotterill formed a successful partnership on their return to New Zealand, as did Hugh Grierson, Kenneth Aimer, and Malcom Draffin ("Auckland War Memorial” 1923: 7). R. Atkinson Abbott, Alva Bartley, Roy Binney, William Gummer, George Hart, Horace Massey, and William Trengrove all established successful practices on their return home. The oldest of the former AA students in the family tree are Samuel Hurst Seager (Lochhead 1996) ${ }^{2}$ and Clere, whose partner L. E. Williams was also an AA alumnus ("Llewellyn Edwin Williams" 2016). The youngest of the cohort, Amyas Connell (1901-1980) and Basil Ward (1902-1976), established their careers in Britain where the firm of Connell, Ward \& Lucas was "short-lived but hugely influential” (“Connell, Ward \& Lucas” n.d.).

\section{Study in the Aftermath of War}

Service abroad during World War I gave a large number of New Zealanders the opportunity to study at the AA. Of the architects and architecture students whose names are inscribed in the Online Cenotaph, hosted by the Auckland War Memorial Museum, $13 \%$ were students of the AA during the first three decades 
of the twentieth century. AA President Maurice Webb acknowledged the presence of between 60 and 70 men from overseas who were attending the school in 1919, and was reported as saying that "their presence would spread a knowledge of English architecture throughout the world, and bring a fresher outlook to England" ("New Zealand Architectural Students at Home" 1919: 11; Webb 1919: 175-76, 179). That said, not all of the New Zealanders who attended the AA during the war years went on to practise as architects. Walter D'Arcy Cresswell was one whose study was interrupted by the outbreak of World War I, and after completing his war service, he returned to New Zealand and became an influential literary figure (Broughton 1998).

Of the Kiwis who did not return to New Zealand, one made a particularly notable contribution to the AA itself. William Thorne Wilmot Ching was born in Auckland in 1888 and in 1904 he began his life in architecture in the office of Arthur Wilson. Ching enrolled at the AA in October 1909, at which time he was in the office of J. W. Troup. His application to study was supported by Roy Binney, who had entered the school in the previous year and was then working for Robert Weir Schultz in London. ${ }^{3}$

Ching competed his studies in 1914 and after his war service, for which he received a Military Cross, he returned to the AA as a house master at Bedford Square ("Military Cross Won" 1916: 9). Despite the fact that he remained for only four years, resigning to set up a heating engineering firm with F. B. Craig in 1923, he was evidently fondly remembered after his sudden death in 1924, resulting from the after-effects of his wartime poison gassing. Ching's Head, a student bar established in 1926, was named in his honour, as was Ching's Yard, an internal courtyard space that is known for its happenings and performances (Bottoms 2016: 60-65). Ching was recently described as an Englishman on the AA Conversations website, an error that cannot fail to grate with Kiwis who take pride in successful and influential expatriates (Pierce 2013).

Another New Zealander who studied at the AA, H. Anthony Mealand (1894-1968), did not return home for many years. Supported in his membership application by Horace Massey (1895-1979), Mealand gained a Certificate in Town Planning at the AA in 1921 and was later co-author of Sir Patrick Abercrombie's "A Plan for Bath" in 1945 ("Personal” 1921a: 14).

Even before the war had officially ended, New Zealand servicemen were being given scholarships to attend the AA. Lance-Corporal Alfred John Brown (18931976), of the New Zealand Engineers, for example, was awarded a scholarship by the Lord Kitchener Memorial Fund in July 1918 ("Soldier Scholarships" 1918: 3; Willis 2013: 966). Brown later practised architecture in Auckland and, after 1930, town planning in Australia (Proudfoot 1993).

Horace Massey wrote to the editor of Progress in April 1919, describing his experience at the AA. Massey reported that "New Zealanders have stormed the Architectural Association" and there were at least 16 such students studying at Bedford Square. "The chance is ours now so I intend to avail myself of the opportunity before returning to good old New Zealand.” The letter concluded by Massey saying he wished to keep up his subscription to Progress, in order to stay abreast of "things architectural at home" and that he was looking forward to his discharge from the army later in the month (Massey 1919: 13). 


\section{The Measure of Success}

"Success in Competitions" by New Zealanders attending the AA was proudly reported in the local press. In January 1920, for example, the Evening Post noted E. W. (Ted) Armstrong, previously of the Wellington Infantry Regiment, had been studying at the AA since February 1919 and had just passed the examination to become an Associate of the Royal Institute of British Architects (RIBA). The Post

\section{New Zealand Architectural Students in London.}

Mr. Horace L. Massey, of Auckland, who was a frequent competitor in Prøgress Competitions be. fore he enlisted, has sent us the following letter:-

C/o. Architectural Assciation, 35 Bedford Square, London, W.C. 1, April 20th 1919.

Fig. 2 In 1919, Horace Massey used the AA as his mailing address. [Progress, August 1, 1919, 13. PapersPast, National Library of New Zealand, Wellington] reported that Armstrong, who intended to go to America after he finished at the AA, had recently come third in a Daily Mail competition for labour-saving homes ("New Zealand Architectural Students" 1920: 15; "NZ Architectural Students" 1920a: 6; "NZ Architectural Students" 1920b: 6). In 1921, the Herald reported that Armstrong, along with fellow New Zealanders Eric Arthur and James White, had been shortlisted for Rome scholarships in architecture ("Rome Scholarship" 1921: 7). After the final design test, for a university arts hub, Armstrong was awarded second place and thus secured the two-year Henry Jarvis studentship, valued at $£ 250$ per annum ("Personal” 1921a: 12). Armstrong ultimately established a practice in London, in 1932 (Gatley 2007: 38).

Like fellow students A. P. Morgan and Massey, Armstrong had secured a New Zealand Expeditionary Force scholarship of $£ 200$ per annum for three years at the end of the war. Morgan and Massey had placed fourth in the aforementioned Daily Mail design competition and the duo placed second and third respectively in another competition for a town planning scheme for Oxford. The same Evening Post article listed Messrs E. T. Marr, G. Downer, E. S. C. Miller, H. F. Butcher, A. J. Brown, and J. H. White as other New Zealanders studying in London at that time ("NZ Architectural Students" 1920a: 6). Henry Butcher appears to have attended the AA briefly before being awarded the Lever prize to fund his studies in town planning at London University in 1920 . He was appointed as a town planner in Wellington in 1927 and was an active member of the profession in the 1930s (“Personal” 1920: 7; “Town-Planning Expert” 1927: 10).

Not all of these men's names appear in the school's Membership Nominations and Applications records for the period 1904-27, which suggests not all applied for membership during or after their studies. J. H. White, for example, is not listed in the membership records but was noted in both the New Zealand Herald and the Architectural Association Journal as enjoying success while a student at the AA ("Annual Prize Distribution" 1920; "Architect's Success" 1921: 8; "Personal Items" 1922: 10). In 1921, White was joint winner of the Society of Architects" Victory Scholarship, which was open to "all students of the Empire under thirty-five" ("Personal” 1921b: 63; see also "Architect's Success" 1921: 8). After his 


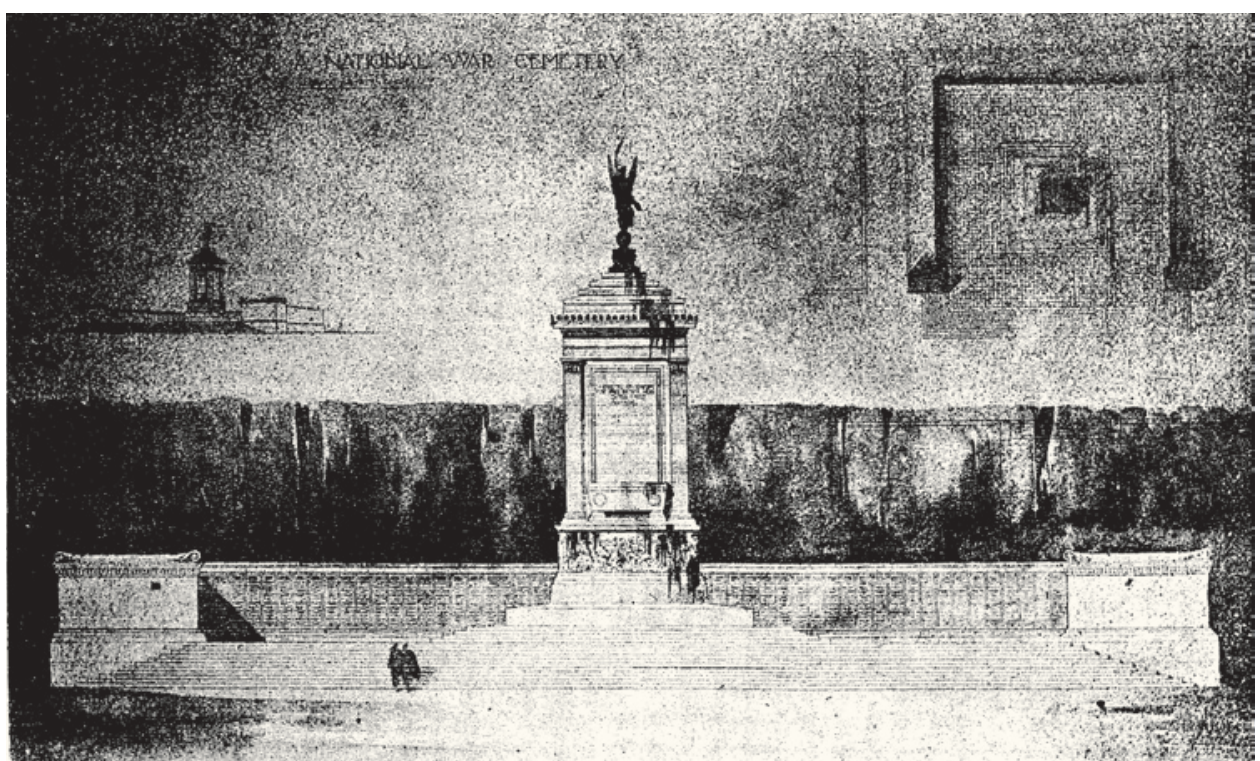

\section{Auckland War Memorial.}

The winning design of the projected Memorial Museum, as prepared by Arckland architects for the open competition, which attracted designs from many different countries, has gained marked approval from numerous experts. The Mayor has received a letter from the Director of Education, Mr. R. Atkinson, under the London Architectural Association, who expresses pleasure at the success of old students of the Association's school, and congratulates Messrs. Draffin and Grierson upon their fine design. Mr. Atkinson adds that, generally speaking, New Zealand students make the best use of their time at the school, and are by far the best of the oversea students.

Fig. 3 A. M. Bartley's design for a Central Monument for the National War Cemetery, France. [Progress, December 1, 1919, 11. PapersPast, National Library of New Zealand, Wellington]

Fig. 4 The AA's Director of Education, Mr A. Atkinson, sang the praises of the School's New Zealand students. [Progress, March 1, 1923, 7. PapersPast, National Library of New Zealand, Wellington] return to New Zealand in early 1922, White made a study tour of the United States with fellow AA graduate Horace Massey and later, in 1927, formed a partnership in Dunedin with another alumnus, Eric Miller, which became one of the leading firms in the city.

Christchurch man Edward Dowling won the Year Prize in his fourth year of study at the AA in 1932 (Untitled 1932: 14). It was reported from London that Dowling had "taken the opportunity, during his vacations, of touring on the Continent and in England and Scotland, always with the object and [sic] studying the architecture of the various countries" ("Architecture" 1932: 16). Dowling (1906-1986), who had been a member of the Christchurch Architectural Students' Association before he left for London, was to remain in Britain after he completed his studies and practised in England before retiring to Scotland ("Architectural Students" 1926: 3; "Edward Thorne Dowling" n.d.; "St Andrew's" 1934: 7; "Work of a Christchurch Architectural Student” 1933: 14). James Hall-Kenney (Wellington and Napier) was another reported as having toured the west of England and the Midlands during his studies at the AA in London ("New Zealanders Abroad" 1936: 18).

The same Evening Post report that celebrated Dowling's success noted that Miss M. J. Blanco-White, who was the recipient of a Holloway Scholarship and 


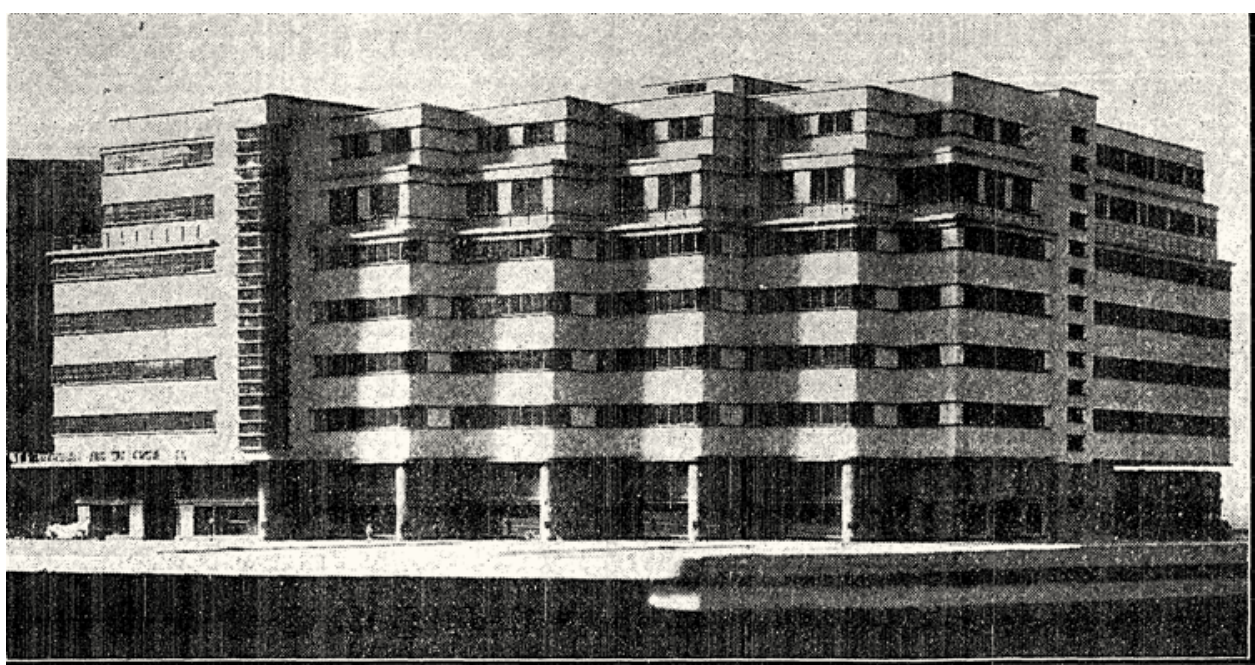

WORK OF A CHRISTCHURCH ARCHITECTURAL STUDENT.-A set of drawings and a model of a large draper, store were the work of MrE.T. Dowling (formerly of Canterbury College in his last term at the Architectural A ssociation
school of Architecture, London. He has been atwarded a fifth year travelling studentship and a special draughtsmanship prize.

Fig. 5 E. T. Dowling's final-year AA project. [Press, August 24, 1933, 14. PapersPast, National Library of New Zealand, Wellington] the AA's Travelling Studentship, had completed her third year and that Miss Beryl Bickerton had gained an honourable mention in her fifth year ("London Personals” 1934: 15). (Margaret) Justin Blanco-White (1911-2001) was a Scottish architect but, as the granddaughter of Liberal politician William Pember Reeves, her success was evidently considered to be of interest to a New Zealand audience (“(Miss) Margaret Justin Blanco White” n.d.). Bickerton is discussed below.

Reginald Uren's "Success in Architecture" was reported by the Evening Post in November 1933 under the headline "Making a Name: Petone Boy at Home" (1933: 3). Uren (1906-1988) had won $£ 350$ for his design for a new town hall for Hornsey Borough in London ("Unique Award" 1936: 9). The Post reported that 280 architects had entered the competition. The value of the town hall was then costed at $£ 200,000$ and the architect's fees were estimated at $£ 5000$. Uren’s father-in-law was quoted as saying that after Uren's earlier (1927) success in the design competition for the Petone foreshore, "New Zealand was too small for him" ("Making a Name" 1933: 3). ${ }^{4}$

\section{A Space for Women}

Not only did the AA welcome New Zealand ex-servicemen, but it also offered educational opportunities for female would-be architects. In 1917, the Auckland Star reported that the "Architectural Association, founded in 1847, is throwing open its doors to women" ("Women Architects" 1917: 16). Noting that the "scarcity of male students-there are only 20, compared with the usual 150-may have had some influence on the Council's decision", the newspaper implied that the AA path to the profession might be more accessible to women than the article system, for which "even women of the comfortable classes hesitate before asking their parents to article them to a calling demanding ... a premium of 300 guineas or more" (see also "Hard Hit" 1915: 17). Membership of the AA subsequently became available to women in 1920, and by 1923 it was reported as having about 30 female students out of a student body of 200 ("Women as Architects" 1923: 36). Crinson and Lubbock state that the school quickly became "the most attractive venue for women [architectural] students” in Britain (1994: 84). 
Alison Sleigh (1898-1972) became an Associate of the RIBA in June 1927, "the first lady student from New Zealand to gain this distinction" ("Miss Alison Sleigh" 1927: 11). Sleigh had studied art at Canterbury College and then entered Samuel Hurst Seager's office in 1917 to serve her articles. She completed these in Cecil Wood's office and subsequently headed to England in April 1921 to attend the AA.

Sleigh had meant to stay in London for two years but changed her plans so that she could complete the full course of study needed for associateship of the RIBA ("NZ Students" 1921: 3). In 1925, she placed second in the Tite Prize: "this prize is awarded for a purely practical subject, with full details of construction, so that for a woman to be placed second in this competition was indeed a very high honour" ("Miss Alison Sleigh" 1927: 11). As Julia Gatley has recounted, Alison Sleigh married a fellow AA graduate in 1928 and continued to practise architecture until her retirement in 1957 (2007: 20-45).

Another female attendee of the AA was Beryl Bickerton (1905-ca. 1996), the granddaughter of Professor A. W. Bickerton, a foundation lecturer at Canterbury College in Christchurch ("Bickerton, William Henry" n.d.). Beryl Bickerton worked in the office of Collins \& Harman before studying in London and receiving an Honourable Mention on completion of her fifth year at the AA in 1932. In the same year, she was identified as the "first Christchurch girl" to be eligible to use the letters ARIBA, after studying "at a famous architectural school at Bedford Row, London" ("Personal Notes" 1932: 15). (It seems Cantabrians had forgotten Sleigh by this time). Bickerton practised under her maiden name after her marriage and news of her professional successes was reported in local newspapers (“London Personals" 1934: 15; "London Personals" 1936: 16).

Meanwhile, back at (lower case) home, it was not until 1933 that Merle Greenwood became the first female graduate of the School of Architecture in Auckland, suggesting that the AA gave New Zealand female architects a head start on their stay-at-home "sisters", in a similar way that going overseas opened doors for female painters and writers who might have been constrained by family responsibilities and social expectations (Willis \& Burns 2017; c.f. Gill 1993). With reference to training in architecture at the AA, Willis and Burns acknowledge that " $[\mathrm{m}]$ ore objective entry criteria encouraged women to qualify, yet most women found their subsequent careers circumscribed by social mores and expectations" (2017: 134).

\section{The AA as Local Role Model}

The AA's twin foci of student-led design and formalisation of professional standards appears to have influenced the profession in New Zealand, just as it did in Australia, in the formation of the University of Melbourne's Architectural Atelier in 1919, for example (Crinson \& Lubbock 1994: 56; Willis 2013). Former student Samuel Hurst Seager described the AA as the "parent association" of that formed in Christchurch in 1915 (Seager 1915: 19). The Auckland Architectural Students' Association (AASA) had been formed in the winter of the previous year; inaugural officeholders included W. H. Gummer (president), Horace Massey (secretary), and Alfred Morgan. Gummer had applied for membership of the AA in 1908, whereas Morgan was an NZ Expeditionary Force applicant in October 1918, and Massey, who had worked under Gummer, applied in May 1919. All three men maintained their membership of the AA into the 1920s. At the AASA's third 
meeting in July 1914, Noel Bamford, who later became the first Director of the School of Architecture at Auckland University College, gave a talk about the competition topic he had set members of the association: "A Bath House in a Thermal District" ("Architectural Students" 1914: 5; Treep 2017: 15). Gummer was appointed patron when the association was revived in 1921 ("Auckland Architectural" 1921: 9). ${ }^{5}$

News of the Wellington Architectural Association's (WAA) first year of activities was published in Progress in July 1922 ("Wellington Association's Growth" 1922: 9). An earlier association had been established in 1918 and was revived briefly by AA member Frank Greenish in 1920 (Untitled 1919: 8). In 1921, the WAA met one or two nights a week, initially in a studio in the Free Kindergarten Building in Taranaki Street, under the patronage of Stanley Fearn ("Wellington Architectural" 1921: 57). It was reported in 1922 that the WAA had become affiliated with the NZIA's scheme for holding competitions amongst the four architectural associations around the country, and that this had led to an improvement in the standard of work of the WAA's 11 members. The same Progress article reported that one of the association's committee members, John D'Oyly, had left during the year to continue his studies (“Wellington Association’s Growth" 1922: 9). D'Oyly applied for membership of the AA in London in October $1922 .{ }^{\circ}$

In Christchurch, the Architectural Association (formerly the Christchurch Architectural Students' Association, est. 1915) also hosted talks and ran student design competitions ("Christchurch Architectural" 1915: 20). In 1934, for example, R. A. Campbell, the engineer for the new State Insurance Building in Worcester Street, gave a talk to the association about the structural design of the building ("Architectural Association" 1934: 3; "Christchurch Architectural" 1934: 16). In 1945, student design competitions were held for a hillside house, a concrete water tower, a petrol station, and a domestic laundry ("Address" 1945: 6; "Architectural Association" 1945: 6; Untitled 1945: 4). Theo Schoon presented a lecture on modern architecture to the association in the spring of 1939, evidently beginning his talk with a quote from the "famous American architect" Frank Lloyd Wright ("Architectural Association” 1939: 6).

The AA had a physical presence in New Zealand in 1927, when it toured a collection of architectural drawings ("Architectural Association" 1927: 13; "Institute of Architects" 1927: 11). The Otago Daily Times described the origins of the AA as an entity "for the purpose of encouraging and providing facilities for the study of architecture", which had developed into a day school after 1900. By 1927, a fiveyear programme was offered by the AA and its school was reported to be "the largest in the British Empire, and usually has nearly 200 students attached to it, some of them coming from remote parts of the world". Examples of drawings and watercolours by students at all year levels were then being shown in Dunedin.

Fig. 6 Margaret Hamilton, following her success in a Christchurch Architectural Association competition. [Press, December 20, 1938, 2. PapersPast, National Library of New Zealand, Wellington] The New Zealand tour was augmented by drawings from schools of architecture in Australia, from whence the AA collection had arrived in New Zealand (“Architectural Drawings" 1927: 4).

\section{An Influential Experience?}

It is difficult to quantify the value of an Architectural Association education for New Zealand architects and planners, beyond making some general comments about the professional success and standing that they later attained. 
Government scholarships for military personnel enabled some to pursue their studies at the AA sufficient to qualify as an associate of the RIBA. Scholarships announced in June 1919 for Messrs Baker, Gordon, Haigh, Reidy, Downer, Miller, Butcher, Marr, and Reid were evidently tagged to specialism in town planning. "The Education Department has already done something in this direction of enabling its architectural students to visit under expert guidance such schemes of town-planning as are regarded as models-Bournemouth, and Port Sunlight, Wavertree (Liverpool) and Letchworth” (“NZ Architectural Skill” 1919: 7).

There was certainly some public awareness of the overseas experience of the New Zealanders who attended the AA, but whether that awareness was translated into anything more tangible than professional networking opportunities is hard to determine. In one isolated incident, it was noted in a letter to the editor of the Hastings Standard in October 1920 that the taxpayer contribution to AA study for returned servicemen might reasonably be expected to see a return in the form of an open competition to appoint an architect for the Hawke's Bay Fallen Soldiers' Memorial Hospital (1927-28) (“Soldiers' Memorial” 1920, October 7: 6). The letter writer got support from at least one other correspondent to the newspaper but in the event, and after considerable delay, the hospital was built to the design of the Government Architect, J. T. Mair (“Hawke’s Bay” 1926: 1; "Soldiers' Memorial” 1920, October 9: 4; “Tenders” 1925: 6).

The AA was a benchmark for the development of the School of Architecture at Auckland University College. Citing the successful experience of Arthur Salmond at the AA after he had graduated from the Auckland programme, the College registrar M. R. O'Shea was reported in 1932 as saying that "it is felt that the Auckland training thus compares very favourably indeed with the work of the leading Home universities" ("Aucklander's Success" 1932: 5; see also "Study of Architecture" 1932: 10). Five years later, members of the Auckland Architectural Students' Association held their annual "Studio Stampede" at the College. "Plain and fancy dress was optional and many original costumes were seen in the large attendance of dancers" ("Studio Stampede" 1937: 3). The Dean of the Faculty, Professor Cyril Knight, welcomed the attendees and the Herald went to some lengths to list all of the women present.

The 1966 Encyclopaedia of New Zealand included a section on expatriates, including the biographies of New Zealanders who had "made names for themselves in their respective professions" ("United Kingdom” 1966). Architects Reginald Uren and Basil Ward in England, Eric Arthur in Canada, and Charles Honey in Malaysia were profiled in the encyclopaedia. By contrast, whereas individual expatriate scientists, artists, writers, and performers are featured in Te Ara-The Encyclopedia of New Zealand, the online encyclopaedia's architectural content is largely focused on typology rather than individual practitioners or the development of the profession, including its education pathways. Perhaps the story of New Zealand architecture has been so closely aligned with that of incomers, including the émigré architects of the post-World War II period and their modernist influence, that the story of the "out-goers" has been sidelined since the 1960 s. 


\section{Conclusion}

The traffic between New Zealand and the Architectural Association continued well beyond the early twentieth century. To take one example, Englishman David Sayers studied at the AA for five years from 1948 before emigrating to New Zealand in 1953. In the book chronicling his career that he self-published in 2010, Sayers acknowledged help from fellow AA alumnus Reg Uren in securing a shortterm job with the Government Architect's office in Wellington, which was the beginning of his New Zealand practice. Uren was the NZIA representative on the council of the RIBA from 1946 until at least 1966 (“United Kingdom” 1966).

In late 1954, Sayers took up a junior partnership with Frank Gillman, and so began a 30-year career in Hamilton specialising in the design of hospitals and, to a lesser extent, dairy factories. Sayers recalled that the practical experience he gained at the AA, working on "a bomb site which was used for practical building instruction ... stood me in good stead in later years" (2010:216).

"In good stead" might well describe the value of the AA to all of the New Zealand architects who passed through its doors. For many, study at the AA was likely the silver lining "OE" experience arising out of their wartime service. Most returned to New Zealand, some to become leaders in their profession. A handful remained abroad but were still claimed as New Zealanders in the mid-twentieth century, just as we claim writer Katherine Mansfield, artist Frances Hodgkins, and pre-eminent physicist Ernest Rutherford today (Priestley 2018; Swarbrick 2014). In contrast to the visibility of this cohort, however, those New Zealand architects who chose to live as expatriates are now little known beyond academic architectural circles.

For the returnees, study at the AA became one of the ingredients in their professional standing and success in New Zealand. Having recently celebrated the centenary of the University of Auckland's School of Architecture and Planning, it seems timely to acknowledge another link in the chain of the global development of architectural education to which the School belongs.

\section{Acknowledgements}

This paper draws upon archival research undertaken at the Architectural Association in May 2000. Historic records accessed at that time included AA Membership Nominations and Applications (1904-27), the AA Card Index List of Members (to ca. 1905), the AA Day School Students' Register (1901-14), the AA Evening School Students' Register (1908-09 and 1913-14), AA Subscriptions (1911-28), and the AA Record Books (192024). Various issues of the $A A$ Journal were consulted at the same time. 
\& other New Zealanders in the past that I felt it a necessary thing for Mr Morton to meet you as soon after his arrival [in London] as possible". Herbert [sic] Conrad Morton, AA Session 1921-1922, No. 127, May 30, 1922, AA Membership Nominations and Applications, 1904-27, Box F505, G-N, Architectural Association, London.

${ }^{6}$ John R. D'Oyly, AA Session 1922-1923, No. 24, October 20,1922, AA Membership Nominations and Applications, 1904-27, Box F504, A-F, Architectural Association, London.

${ }^{7}$ Conversely, when Wellingtonborn George Robb applied to study at the AA in October 1905 his letter of support from Ernest Wellman of Johannesburg, South Africa, stated that "[Robb] has had a good practical experience \& now desires to study more particularly the architectural \& artistic side of the profession". AA Membership Nominations and Applications, 1904-27, Box F506, O-W, Architectural Association, London. See also "Personal" (1917: 24). work abroad. Historically, Zealanders' "OE" was undertaken in Britain, typically London.

${ }^{2}$ According to his Dictionary of New Zealand Biography entry, Seager studied at the AA, as well as University College, the National Art Training Schoo (later the Royal College of Art), and the Royal Academy of Arts, in 1882-83 (Lochhead 1996; "Obituary" 1933: 13).

${ }^{3}$ Wilmot L. Ching, AA Session 1909-1910, No. 31, October 4, 1909, AA Membership Nominations and Applications, 1904-27, Box F504, Architectural Association, London.

${ }^{4}$ Uren had won the Petone design competition in association with C. T. Natusch \& Sons, of which Stanley Natusch also studied at the AA immediately after World War I ("Petone Foreshore" 1927: 17). See also Stanley Natusch, AA Session 1919-1920, No. 27, July 1, 1919, AA Membership Nominations and Applications, 1904-27, Box F505, G-N, Architectural Association, London.

${ }^{5}$ Gummer wrote a letter in support of H. C. Morton's application to the AA in 1922, stating that "[s]uch has been your kindness \& help to myself

(1945, July 3). Press, p. 6.

Annual prize distribution. (1920)

Architectural Association Journal, 35(402), August, 29.

Architect's success: Victory scholarship. (1921, October 20). New Zealand Herald, p. 8.

Architectural Association. (1934, January 30). Press, p. 3.

Architectural Association. (1945, May 8). Press, p. 6.

Architectural Association: Exhibition of drawings. (1927, March 23). Otago Daily Times, p. 13

Architectural Association Lecture by Mr. T. H. Schoon. (1939, September 5). Press, p. 6.

Architectural drawings: Valuable exhibits. (1927, March 24). Press, p. 4.
Architectural students: Annual meeting. (1926, December 3).

Press, p. 3 competition. (1914, July 6). New Zealand Herald, p. 5.

Architecture: Promising students. (1932, September 27). Evening Post, p. 16.

Auckland Architectural Students' Association. (1921, June 1). Progress, 9.

Auckland War Memorial. (1923, March 1). Progress, 7.

Aucklander's success: Architectural student; Work at London School. (1932, June 6). Auckland Star, p. 5.

Barrie, A. (2008). New Zealand Architecture Family Tree. Version 1.0, May. Retrieved from http:// www.architecture-archive. auckland.ac.nz/docs/blockdigital/2008-05-Block-DigitalFamily-Tree.pdf

Bickerton, William Henry. (n.d.). In Early New Zealand Photographers and their

Successors. Retrieved from http:// canterburyphotography.blogspot. co.nz/2017/07/bickerton-williamhenry 7.html

Bones, H. (2018). The expatriate myth: New Zealand writers and the colonial world. Dunedin: Otago University Press.

Bottoms, E. (2016). AA

Personalities No. 3: W. T. W. Ching. AArchitecture, 27, January, 60-65. of New Zealand. Retrieved from https://teara.govt.nz/en/ biographies/4c42/cresswellwalter-darcy

Christchurch Architectural Students' Association. (1915, June 1). Progress, 20

Christchurch Architectural Association. (1934, April 11). Press, p. 16.

Clere, F. de J. (1917, September 1). A cathedral design. Progress, 16.

Connell, Ward \& Lucas. (n.d.). In The modern house: Directory of architects and designers. Retrieved from http://www. themodernhouse.com/directoryof-architects-and-designers/
Architectural students: The first

connell-ward-and-lucas/

Crinson, M., \& Lubbock, J. (1994). Architecture: Art or profession? Three hundred years of architectural education in Britain Manchester and New York: Manchester University Press.

Dunn, M. (1984-85). The other expatriate. Art New Zealand, 33, Summer. Retrieved from http:// www.art-newzealand.com/ Issues31to40/mcintyre.htm

Edmond, M. (2017). The expatriates. Wellington: Bridget Williams Books.

Edward Thorne Dowling. (n.d.). In Dictionary of Scottish Architects (DSA) architect biography report. Retrieved from http:// www.scottisharchitects.org.uk/ architect full.php?id=403780

F. de J. Clere, FRIBA. (1917, August 1). Progress, 12.

Gatley, J. (2007). Alison Shepherd (nee Sleigh), ARIBA: "Success of New Zealand Lady Student" revisited. Fabrications: The Journal of the Society of Architectural Historians, Australia and New Zealand, 17(1), June, 20-45. http://dx.doi.org/10.1080/1 0331867.2007.10539598

Gatley, J., \& Douglas, C. (Eds.). (2008). Interstices: Journal of Architecture and Related Arts, 9, Expat: Places/Spaces/Baggage. Retrieved from http://interstices. ac.nz/published-journals/ interstices-09/

Gatley, J., \& Treep, L. (Eds.). (2017). The Auckland School: Broughton, W. S. (1998). Cresswell, 100 years of architecture and Walter D'Arcy. Dictionary of New planning. Auckland: School Zealand Biography. Republished of Architecture and Planning, in Te Ara-The Encyclopedia University of Auckland.
Gill. L. (1993). Hodgkins, Frances

Mary. In Dictionary of New

Zealand Biography, Volume

Two, 1870-1900. Wellington: Department of Internal Affairs and Bridget Williams Books. Republished in Te Ara-The Encyclopedia of New Zealand. Retrieved from https://teara. govt.nz/en/biographies/2h41/ hodgkins-frances-mary

Hard hit by war. (1915, June 1). Progress, 17.

Hawke's Bay Fallen Soldiers' Memorial Hospital. (1926, October 22). Manawatu Times, p. 1. 
Industrial Association. (1880,

August 25). Lyttelton Times, p. 3.

Institute of Architects. (1927,

November 18). Evening Post, p. 11.

Labour disputes in England. (1891, October 19). New Zealand Herald, p. 5 .

Llewellyn Edwin Williams, 1884-1967. (2016). In Wellington heritage, Wellington City Council. Retrieved from http://www. wellingtoncityheritage.org.nz/ architects/llewellyn-edwinwilliams

Lochhead, I. J. (1996). Seager, Samuel Hurst. Dictionary of New Zealand Biography, Volume Three, 1901-1920. Auckland: Auckland University Press; and Wellington: Department of Internal Affairs. Updated May 2002, in Te Ara-The Encyclopedia of New Zealand. Retrieved from https://teara.govt. nz/en/biographies/3s8/seagersamuel-hurst

London personals. (1934, September 28). Evening Post, p. 15.

London personals. (1936, December 8). Evening Post, p. 16.

Maclean, S. (1993). Clere,

Frederick de Jersey, Dictionary of

New Zealand Biography, Volume

Two, 1870-1900. Wellington:

Department of Internal Affairs and Bridget Williams Books. Republished in Te Ara-The Encyclopedia of New Zealand. Retrieved from https://teara.govt. nz/en/biographies/2c22/clerefrederick-de-jersey

Making a name: Petone boy at home; Success in architecture. (1933, November 22). Evening Post, p. 3.

Massey, H. L. (1919, August 1). New Zealand architectural students in London. Progress, 13.

McEwan, A. (1999). Learning by example: Architectural education in New Zealand before 1940. Fabrications: The Journal of the Society of Architectural Historians, Australia and New Zealand, 9, May, 1-16.

Military Cross won: Another Auckland boy; Lieut. Wilmot Ching. (1916, October 5). New Zealand Herald, p. 9

Miss Alison Sleigh, ARIBA. (1927, December 15). Evening Post, p. 11.
(Miss) Margaret Justin Blanco White. (n.d.). Dictionary of Scottish Architects (DSA) architect biography report. Retrieved from http://www. scottisharchitects.org.uk/ architect full.php?id $=400816$

New Zealand architectural students at home. (1919, December 1). Progress, 11.

New Zealand architectural students: Success in competitions. (1920, February 3). Otago Witness, p. 15

New Zealanders abroad: Personal notes from London. (1936, April 2). Press, p. 18

NZ architectural skill. (1919, July 25). Auckland Star, p. 7.

$\mathrm{NZ}$ architectural students: Success in competitions. (1920a, January 17). Evening Post, p. 6.

NZ architectural students: Success in competitions. (1920b, February 2). Otago Daily Times, p. 6.

NZ students at home. (1921, June 22). Press, p. 3.

Obituary: Mr. Samuel Hurst Seager; New Zealand architect. (1933, October 5). Evening Post, p. 13.

Personal. (1917, June 1). Progress, 24.

Personal. (1920, August 6)

Taranaki Herald, p. 7.

Personal. (1921a, September 1). Progress, 12-14.

Personal. (1921b, November 1). Progress, 63.

Personal items. (1922, January 21) New Zealand Herald, p. 10.

Personal notes. (1932, July 21). Evening Post, p. 15

Petone foreshore: Improvement scheme; Prize-winning proposals. (1927, May 25). Evening Post, p. 17.

Pierce, C. (2013). "Ching”: A short etymological exposé. AArchitecture, 20, October 22. Retrieved from http:// conversations.aaschool.ac.uk/ ching-a-short-etymologicalexpose/

Priestley, R. (2018). Physics, chemistry and mathematics: New Zealand physicists overseas. In Te Ara-The Encyclopedia of New Zealand. Retrieved from https:// www.teara.govt.nz/en/physics- chemistry-and-mathematics/ page-3

Proudfoot, H. (1993). Brown, Alfred John (1893-1976). In John Ritchie (Ed.), Australian Dictionary of Biography, Volume 13, 1940-1980. Melbourne: Melbourne University Press. Retrieved from http://adb.anu. edu.au/biography/brown-alfredohn-9596/text16915

Rome scholarship: Success of New Zealanders. (1921, April 2). New Zealand Herald, p. 7.

Sayers, D. (2010). The goodwill years: The remarkable story of a professional partnership. Hamilton: SFT Books.

Seager, S. Hurst. (1915, November 1). Architects' Institute and the student. Criticism answeredwho founded the Students' Association? Progress, November, 19

Soldier scholarships: Two more nominations. (1918, September 5). Evening Post, p. 3.

Soldiers' Memorial architects. (1920, October 7). Hastings Standard, p. 6.

Soldiers' Memorial architects. (1920, October 9). Hastings Standard, p. 4

St Andrew's College: Annual meeting of board of governors. (1934, April 10). Press, p. 7.

"Studio stampede": Architects' gay night; The College dance. (1937, July 19.) New Zealand Herald, p. 3.

Study of architecture: Success in England. (1932, June 6). New Zealand Herald, p. 10.

Summerson, J. (1947). The Architectural Association 1847-1947. London: Architectural Association.

Swarbrick, N. (2014). Creative and intellectual expatriates: Expatriation to Britain. In $T e$ Ara-The Encyclopedia of New Zealand. Retrieved from https:// www.teara.govt.nz/en/creativeand-intellectual-expatriates/ page-3

Tenders: Massey, Hyland and Phillips. (1925, March 21). New Zealand Herald, p. 6.

Town-planning expert: Wellington appointment; Selection of Mr. $\mathrm{H}$. Butcher. (1927, August 17). New Zealand Herald, p. 10
Treep, L. (2017). “ A school of architecture for the dominion": The first years. In J. Gatley \& L. Treep (Eds.), The Auckland School: 100 years of architecture and planning (pp. 14-39).

Auckland: School of Architecture and Planning, University of Auckland.

Unique award: Dominion architect; Mr Uren in England. (1936, May 12). New Zealand Herald, p. 9.

United Kingdom. (1966). In

A. H. McLintock (Ed.), An

Encyclopaedia of New Zealand.

Wellington, Government Printer.

Republished in Te Ara-The

Encyclopedia of New Zealand.

Retrieved from https://teara. govt.nz/en/1966/expatriatesbiographies/page-32

Untitled. (1886, February 26).

Evening Post, p. 2.

Untitled. (1919, September 22).

Evening Post, p. 8.

Untitled. (1945, November 14).

Press, p. 4

Untitled photograph of Dowling. (1932, November 25). Press, p. 14

Webb. M. (1919). Presidential address \& prize giving. $A A$ Journal, 35(391), September, 175

Wellington Architectural Students' Association. (1921, November 1). Progress, 57.

Wellington Association's growth and work. (1922, July 1). Progress, 9.

Willis, J. (2013). The Architectural Association and the Architectural Atelier. In A. Brown \& A. Leach (Eds.), Proceedings of the Society of Architectural Historians, Australia and New Zealand: 30 , Open. Gold Coast, Qld: SAHANZ.

Willis, J. \& Burns, K. (2017). The antipodean diaspora, 1920-2000. In E. Darling \& L. Walker (Eds.), $A A$ Woman in Architecture, 1917-2017 (pp. 129-145, 186). London: Architectural Association.

Women architects. (1917, November 17). Auckland Star p. 16.

Women as architects. (1923, March 1). Ladies'Mirror, 36

Work of a Christchurch architectural student. (1933, August 24). Press, p. 14. 